\title{
Strategies Adopted by Women of Rural and Urban Areas for Weight Losspost-Pregnancy
}

\author{
Blessy Mohandass ${ }^{1}$, Amanpreet Kaur ${ }^{2}$; Timsy $^{2}$; Nitika Choudhary ${ }^{3}$, Shivani Rana ${ }^{3}$, Sonaly Robinson ${ }^{3}$ \\ ${ }^{1}$ Nursing Tutor, ${ }^{2}$ Assistant Professor, ${ }^{3}$ B.Sc. Nursing IVth Year Students, Chitkara School of Health Sciences, \\ Chitkara University, Punjab, India
}

\begin{abstract}
Pregnancy is the most important and pleasurable moment in a woman's life when along with the bliss of motherhood, they also tend to gain extra weight. In the field of medicine, health, or physical fitness, weight loss refers to a reduction of the total body mass utilizing various weight loss techniques. Gaining an adequate amount of weight during pregnancy is essential, but it is also crucial that one should lose the extra pounds to decrease the chances of obesity. The study was conducted to assess the strategies used by nursing mothers to reduce their weight after pregnancy residing in rural and urban areas. The study was conducted to find out the strategies adopted by nursing mothers for weight loss. A self-structured checklist having 27 items of common strategies used for weight loss was used to collect data from the participants. The results revealed that nursing mothers residing in the urban area adopted a higher number of weight-loss strategies as compared to nursing mothers residing in the rural area. The findings of the study that the nursing mother residing in the urban area adopted more weight-loss strategies as compared to nursing mothers residing in the rural area. Level of Evidence: Level III, Evidence obtained from well-designed cohort or case-control analytic studies
\end{abstract}

Keywords: Diet, Exercise, Gestational Weight gain, Obesity, Postnatal Weight loss, Pregnancy, Weight Loss.

\section{Introduction}

In the field of health, medicine or physical fettle, weight loss means a decrease in total body mass by a mean decrease in fluid, body fat or adipose tissue or lean mass, i.e., bone mineral deposits, muscle tendon, and other connective tissues. Weight loss can occur either inconspicuously because of malnutrition or disease or even because of a conscious effort emends an actual or perceived overweight or obese condition. "Unexplained" weight loss not due to a drop in calorific intake or exercise is called cachexia and may be a symptom of a severe medical condition. It is commonly known as slim intentional weight loss. "Intentional" weight loss is the loss in total body mass due to efforts

\section{Corresponding Author:}

\section{Blessy Mohandass}

Nursing Tutor, Department of Nursing, Chitkara School of Health Sciences, Chitkara University, Punjab, India to improve fitness \& health or by slimming to change one's physical appearance. Weight loss in plus size or rotund individuals reduces health risks, ${ }^{[1]}$ increases fitness ${ }^{[2]}$, and can delay the onset of diabetes. ${ }^{[1]}$ Weight loss also happens when the body utilizes more energy in work and metabolism than it absorbs from food or other nutrients. It will then utilize stored reserves of fat or musculature, resulting in gradual weight loss. [3] There is also a known dietary modification called 'balanced percentage diets,' which are low-calorie diets. Nutritionists most commonly recommend these types of diets because of their minimal detrimental effects. Besides limiting the intake of calories, a balanced diet regulates the consumption of macronutrients. Research states that $55 \%$ of the total number of allocated daily calories are from carbohydrates, $15 \%$ from protein, and $30 \%$ from fats with no more than $10 \%$ of total fat coming from saturated forms. A recommended 1,200 calorie diet would provide approximately 660 calories from carbohydrates, 180 from proteins, and 360 from fats, for example. Some studies suggest that increased 
protein consumption can help alleviate hunger pangs associated with lower calorie intake by increasing the sensation of safety. ${ }^{[4]}$ Depression, stress, or boredom can also contribute to weight gain ${ }^{[5]}$, and people are advised to seek medical assistance in these cases. A 2010 study found that dieticians who had a full night's sleep lost more than twice as much fat as dieticians with sleep deprivation. ${ }^{[6][7]}$ Although vitamin D supplementation might help, studies have not supported this ${ }^{[8]}$, a majority of dieters regain the lost weight. ${ }^{[9]}$ According to the American Dietary Guidelines, those who and manage a healthy weight do so most successfully by being careful to consume just enough calories to meet their needs and be physically active. ${ }^{[10]}$ Very few studies are conducted in India that explore post-pregnancy weight control by women. The proportion of women holding $5 \mathrm{~kg}$ or more after six months of post-partum ranged from $14 \%$ to $20 \%$ in various studies. ${ }^{[11]}$ Recent studies suggest that gestation, along with physical activity behavior among females, can be a powerful teachable movement to promote a healthy diet and eating practices. Appropriate physical exercise and a balanced diet for nutrition might help cut extra pounds. Managing obesity can include lifestyle changes, medications, or surgery. The first intervention for obesity is dieting and physical exercise. ${ }^{[12]}$ Diet modifications may produce weight loss over the short term, ${ }^{[13]}$ but maintaining this weight loss is often complicated and many times requires making exercise and lower-calorie diet, a permanent part of an individual's lifestyle ${ }^{[14]}{ }^{[15]}$ The success rates of longterm weight loss maintenance with lifestyle changes are low, ranging from only 2 to $20 \% \cdot{ }^{[16]}$ Dietary and lifestyle changes have also been found to be effective in preventing excessive weight gain during pregnancy and improve the outcome for both the mother and the child. The National Institute of Health recommends a total weight loss goal of $5 \%$ to $10 \%$ of the person's current weight over six months. ${ }^{[17]}$ The present study aims to find the different strategies adopted by nursing mothers of rural-urban areas for weight loss post-pregnancy and delivery.

\section{Materials and Method}

A Non-Experimental Comparative Design was used to find out the strategies adopted for weight control by Nursing Mothers residing in rural and urban areas. Using a Non-probability convenient sampling technique, 50 subjects from rural and 50 from an urban area, a total of 100 nursing mothers were selected. Willing nursing mothers, who were breastfeeding, their child from 03 months up to 01 years after delivery, who were available during data collection, were selected. The investigators developed a self-structured tool after the extensive review of the literature on the relevant topic after discussion with experts and research guides. It consisted of two parts; Part A consisted of demographic variables such as age, education, number of children, mode of delivery, height, type of family, employment status and Part B consisted of self-structured checklist to assess the strategies adopted by nursing mothers for weight control was given to the participant to respond to by tick marking the appropriate point. The checklist had three domains, namely; Exercise having 05 items, Dietary modification having 16 items, and Lifestyle modification containing 06 items. The reliability of the Practice Checklist was checked by Inter- method, which was found to be ' $r$ ' $=0.9$. Formal permission obtained from the office of the Municipal Corporation. The participants were assured of anonymity and confidentiality regarding the data collected. The objectives of the study were explained to the mothers before the data collection, and the checklist was distributed, and data was collected using the paper and pencil method. Ethical clearance was obtained from the Institutional Ethical \& Research Committee.

\section{Results}

Analysis and interpretation of the data were made according to the objectives of the study. Descriptive and Inferential statistics were utilized to interpret the data. They were further explained under various sections. Table 1 shows the frequency and percentage distribution of sample characteristics. It shows that a maximum of $29(58 \%)$ nursing mothers from rural areas were in the group 25-31 years. On the other hand, a maximum of $24(48 \%)$ nursing mothers from urban areas were in the age group above 32 , and the minimum $6(12 \%)$ were in the age group 18-24. When asked about the number of children, $29(58 \%)$ of nursing mothers from rural areas had two children, and 21 (42\%) women had one child. On the contrary, urban areas maximum $25(50 \%)$ of nursing mothers from urban areas had two children, and only $1(2 \%)$ had three or more children. On applying the Chi test for homogeneity between the samples, it was found that there was significant homogeneity in Age, Education Mode of Delivery, and Employment status of the nursing mothers residing in rural and urban areas. Out of a total of 50 nursing mothers, Only four mothers residing in the rural area said that they 'went to the gym,' whereas 14 mothers residing in the urban area chose 'to go to a gym' for weight control. There was a 
significant association $(\mathrm{p}<0.05)$ between the two groups and the 'use of Yoga' as a strategy for weight control in nursing mothers. Out of a total of 50 nursing mothers, 36 mothers residing in the rural area said that they 'drink water before taking meal' whereas 21 mothers residing in the urban area choose to' drink water before taking meal' for weight control. Only ten mothers residing in the rural area and from the urban area 'consulted a dietician' to control their weight. When asked about 'eating calculation/diet chart,' almost the same number of mothers residing in rural are as 13 and 14 in the urban area responded affirmatively. About 32 nursing mothers residing in the rural area and 30 mothers residing in the urban area said that they 'skipped their meals' to control weight. A similar finding was seen where 34 mothers from rural areas and 33 mothers residing in the urban area 'took short and frequent meals.' Less than half 36 residing in rural areas responded that' they opt for healthy snacking (home-cooked less oily food), while 41 mothers residing in the urban area using the same strategy to control weight. Both mothers residing in rural 33 and urban areas 36 said that they preferred to 'eat at home than outside' to control weight. Twentyone nursing mothers residing in rural areas' opted for high fiber diet' while 34 mothers residing in the urban area using the same strategy to control weight. Also, 26 mothers residing in the rural area and 44 from urban areas 'included fresh fruit and vegetables in their diet' to control their weight. When asked, more than half of 36 mothers residing in rural areas responded that they 'take green tea every day' while 41 mothers are residing in the urban area using the same strategy to control weight. About 24 mothers residing in a rural area 'took warm water with few lemons regularly drops' on the other hand, only 16 mothers residing in the urban area used the same approach to control weight. There was a significant association $(\mathrm{p}<0.05)$ between the two groups and 'drinking water before taking meals,' 'consulting a, 'opting for high fiber diet,' 'including fresh and vegetables in my diet,' 'take warm water with few lemons drops regularly,"'stopped taking Oily foods and Caffeine' as a strategy for weight control in nursing mothers. Out of a total of 50 nursing mothers, only 20mothers residing in the rural area said that they take dinner early evening, whereas 10 mothers residing in the urban area chose to take dinner in the early evening for weight control. Only 11 nursing mothers of a rural area and 29 from the urban area took chemical agents/ medication to control their weight. About 20mothers residing in the rural area used to check their weight regularly; on the other hand, 40 mothers residing in the urban area checked their weight regularly. 30nursing mothers residing in the rural area and 34mothers residing in an urban area were motivated to reduce weight. 20mothers from rural areas and 32 mothers residing in urban are as' slept for 6-8 hours straight regularly' to control weight. Only seven mothers residing in rural areas responded that they tried to 'remain stressfree by indulging in leisure activity' while 34 mothers residing in the urban area using the same strategy to control weight. Half, 26, mothers residing in rural areas responded that they drank at least 8-10 glasses of water/ daily, while 34 mothers residing in the urban area used the same strategy to control weight. It was therefore clearly evident that nursing mothers residing in urban areas chose more strategies to control weight such as, take dinner in the early evening, take chemical agents/ medications, check their weight regularly, motivated to reduce weight, sleep for 6-8 hours straight regularly, try to remain stress-free by indulging in leisure activity as compared to nursing mothers residing in rural areas. There was a significant difference $(p<0.05)$ between the two groups and 'taking medications for weight loss,' 'checking weight regularly,' and 'being motivated to reduce weight' as a strategy for weight control in nursing mothers. Table 2 reveals the comparison of significant difference between the two groups trying exercise as a strategy adopted for weight control; it was found that there was a significant difference $(p<0.05)$ between the two groups and 'use of Yoga' as a strategy for weight control in nursing mothers. Table 3 reveals the comparison of significant difference between the two groups trying dietary modification as a strategy adopted for weight control by, on the application of Chi-square test, it was found that there was a significant association $(p<0.05)$ between the two groups and 'drinking water before taking meals," 'consulting a, "opting for high fiber diet,"'including fresh and vegetables in my diet,"'take warm water with few lemons drops regularly,'stopped taking Oily foods and Caffeine' as a strategy for weight control in nursing mothers. Table 4 reveals the comparison of the significant relationship between the two groups trying lifestyle modification as a strategy adopted for weight control by, on the application of Chi-square test, it was found that there was a significant difference ( $p>0.05$ ) between the two groups and 'taking medications for weight loss,' 'checking weight regularly,' and 'being motivated to reduce weight' as a strategy for weight control in nursing mothers. 
Table 1: Frequency and Percentage distribution of Sample Characteristics $N=100$

\begin{tabular}{|c|c|c|c|c|c|c|c|}
\hline \multirow{2}{*}{ Socio Demographic variables } & \multicolumn{2}{|c|}{ Rural $\mathbf{n}=\mathbf{5 0}$} & \multicolumn{2}{|c|}{ Urban $n=50$} & \multirow{2}{*}{ Chi Test } & \multirow{2}{*}{ P Value } & \multirow{2}{*}{ df } \\
\hline & (f) & $(\%)$ & (f) & $(\%)$ & & & \\
\hline $\begin{array}{l}\text { Age(Years) } \\
18-24 \\
25-31 \\
\text { Above } 32\end{array}$ & $\begin{array}{c}13 \\
29 \\
8\end{array}$ & $\begin{array}{l}26 \% \\
58 \% \\
16 \%\end{array}$ & $\begin{array}{c}6 \\
20 \\
24\end{array}$ & $\begin{array}{l}12 \% \\
40 \% \\
48 \%\end{array}$ & 12.232 & $0.002 *$ & 2 \\
\hline $\begin{array}{l}\text { Education } \\
\text { Illiterate } \\
\text { Matriculation } \\
\text { Graduate } \\
\text { Post Graduate }\end{array}$ & $\begin{array}{c}12 \\
37 \\
0 \\
1\end{array}$ & $\begin{array}{c}24 \% \\
74 \% \\
0 \% \\
2 \%\end{array}$ & $\begin{array}{c}1 \\
12 \\
29 \\
8\end{array}$ & $\begin{array}{c}2 \% \\
24 \% \\
58 \% \\
16 \%\end{array}$ & 56.507 & $0.000^{*}$ & 3 \\
\hline $\begin{array}{l}\text { Number of Child } \\
\text { One } \\
\text { Two } \\
\text { Three or more children }\end{array}$ & $\begin{array}{c}21 \\
29 \\
0\end{array}$ & $\begin{array}{c}42 \% \\
58 \% \\
0 \%\end{array}$ & $\begin{array}{c}24 \\
25 \\
1\end{array}$ & $\begin{array}{c}48 \% \\
50 \% \\
2 \%\end{array}$ & 1.496 & $0.473^{\mathrm{NS}}$ & 2 \\
\hline $\begin{array}{l}\text { Mode of Delivery } \\
\text { Normal vaginal delivery } \\
\text { Caesarean }\end{array}$ & $\begin{array}{l}40 \\
10\end{array}$ & $\begin{array}{l}80 \% \\
20 \%\end{array}$ & $\begin{array}{l}23 \\
27\end{array}$ & $\begin{array}{l}46 \% \\
54 \%\end{array}$ & 12.398 & $0.000^{*}$ & 1 \\
\hline $\begin{array}{l}\text { Type of Family } \\
\text { Nuclear } \\
\text { Joint }\end{array}$ & $\begin{array}{c}0 \\
50\end{array}$ & $\begin{array}{c}0 \% \\
100 \%\end{array}$ & $\begin{array}{c}0 \\
50\end{array}$ & $\begin{array}{c}0 \% \\
100 \%\end{array}$ & 0.041 & $0.839^{\mathrm{NS}}$ & 1 \\
\hline $\begin{array}{l}\text { Employment Status } \\
\text { Employed } \\
\text { Unemployed }\end{array}$ & $\begin{array}{l}20 \\
30\end{array}$ & $\begin{array}{l}40 \% \\
60 \%\end{array}$ & $\begin{array}{l}21 \\
29\end{array}$ & $\begin{array}{l}42 \% \\
58 \%\end{array}$ & 15.174 & $0.000^{*}$ & 1 \\
\hline
\end{tabular}

* Significant, NS non significant

Table 2: Comparison of exercise as a strategy adopted for weight control by nursing mothers residing in rural and urban areas $N=100$

\begin{tabular}{|c|c|c|c|c|c|c|}
\hline Exercise as a Strategy & Area & Yes (f) & No (f) & Chi Test & 'p' Value & df \\
\hline \multirow{2}{*}{ I go to a Gym } & Rural $n=50$ & 2 & 48 & \multirow{2}{*}{3.053} & \multirow{2}{*}{$0.081^{\mathrm{NS}}$} & \multirow{2}{*}{1} \\
\hline & Urban $\mathrm{n}=50$ & 7 & 43 & & & \\
\hline \multirow{2}{*}{ I mildly/moderately exercise } & Rural $n=50$ & 21 & 29 & \multirow{2}{*}{1.004} & \multirow{2}{*}{$0.316^{\mathrm{NS}}$} & \multirow{2}{*}{1} \\
\hline & Urban $\mathrm{n}=50$ & 26 & 24 & & & \\
\hline \multirow{2}{*}{ I do yoga } & Rural $n=50$ & 4 & 46 & \multirow{2}{*}{6.775} & \multirow{2}{*}{$0.009 *$} & \multirow{2}{*}{1} \\
\hline & Urban $\mathrm{n}=50$ & 14 & 36 & & & \\
\hline \multirow{2}{*}{ I go for a walk } & Rural $n=50$ & 35 & 15 & \multirow{2}{*}{1.333} & \multirow{2}{*}{$0.248^{\mathrm{NS}}$} & \multirow{2}{*}{1} \\
\hline & Urban $\mathrm{n}=50$ & 40 & 10 & & & \\
\hline \multirow{2}{*}{ I go to dance classes } & Rural $n=50$ & 4 & 46 & \multirow{2}{*}{0.444} & \multirow{2}{*}{$0.505^{\mathrm{NS}}$} & \multirow{2}{*}{1} \\
\hline & Urban $n=50$ & 6 & 44 & & & \\
\hline
\end{tabular}

\footnotetext{
* Significant, NS non significant
} 
Table 3: Comparison of Dietary Modification as a strategy adopted for weight control by nursing mothers residing in rural and urban areas $\mathrm{N}=100$

\begin{tabular}{|c|c|c|c|c|c|}
\hline Dietary Modification as a Strategy & Area & Yes $\mathbf{f}(\%)$ & No $f(\%)$ & Chi Test & 'p' Value \\
\hline \multirow{2}{*}{ I drink 8-10 glasses of water daily } & Ruraln $=50$ & 26 & 24 & \multirow{2}{*}{2.667} & \multirow{2}{*}{$0.102^{\mathrm{NS}}$} \\
\hline & Urbann $=50$ & 34 & 16 & & \\
\hline \multirow{2}{*}{ I drink water before taking meals } & Rural $n=50$ & 36 & 14 & \multirow{2}{*}{9.180} & \multirow{2}{*}{$0.002 *$} \\
\hline & Urban $\mathrm{n}=50$ & 21 & 29 & & \\
\hline \multirow{2}{*}{ I consult a dietician } & Rural $n=50$ & 10 & 40 & \multirow{2}{*}{3.934} & \multirow{2}{*}{$0.047^{*}$} \\
\hline & Urban $\mathrm{n}=50$ & 19 & 31 & & \\
\hline \multirow{2}{*}{ I eat by Calorie calculation/Diet chart } & Rural $\mathrm{n}=50$ & 13 & 37 & \multirow{2}{*}{0.051} & \multirow{2}{*}{$0.822^{\mathrm{NS}}$} \\
\hline & Urban $\mathrm{n}=50$ & 14 & 36 & & \\
\hline \multirow{2}{*}{ I skip my meals } & Rural $n=50$ & 32 & 18 & \multirow{2}{*}{0.170} & \multirow{2}{*}{$0.680^{\mathrm{NS}}$} \\
\hline & Urban $n=50$ & 30 & 20 & & \\
\hline \multirow{2}{*}{ I take short and frequent meals } & Rural $\mathrm{n}=50$ & 34 & 16 & \multirow{2}{*}{0.045} & \multirow{2}{*}{$0.832^{\mathrm{NS}}$} \\
\hline & Urban $n=50$ & 33 & 17 & & \\
\hline \multirow{2}{*}{$\begin{array}{l}\text { I opt for healthy Snacking (Home cooked } \\
\text { less oily food) }\end{array}$} & Rural $n=50$ & 36 & 14 & \multirow{2}{*}{1.412} & \multirow{2}{*}{$0.235^{\mathrm{NS}}$} \\
\hline & Urban $\mathrm{n}=50$ & 41 & 9 & & \\
\hline \multirow{2}{*}{ I eat at home than outside } & Rural $n=50$ & 33 & 17 & \multirow{2}{*}{0.421} & \multirow{2}{*}{$0.517^{\mathrm{NS}}$} \\
\hline & Urban $n=50$ & 36 & 14 & & \\
\hline \multirow{2}{*}{ I opt for high fibre diet } & Rural $\mathrm{n}=50$ & 21 & 29 & \multirow{2}{*}{6.828} & \multirow{2}{*}{$0.009^{*}$} \\
\hline & Urban $\mathrm{n}=50$ & 34 & 16 & & \\
\hline \multirow{2}{*}{$\begin{array}{l}\text { I include fresh fruits and vegetables in my } \\
\text { diet }\end{array}$} & Rural $\mathrm{n}=50$ & 26 & 24 & \multirow{2}{*}{15.429} & \multirow{2}{*}{$0.000^{*}$} \\
\hline & Urban $n=50$ & 44 & 6 & & \\
\hline & Rural $n=50$ & 13 & 37 & 0927 & $5-0 \mathrm{NS}$ \\
\hline I take green tea everyday & Urban $n=50$ & 16 & 34 & $0.43 /$ & $0.509^{100}$ \\
\hline I take warm water with few lemon drops & Rural $n=50$ & 24 & 26 & 7 & $000<*$ \\
\hline regularly & Urban $n=50$ & 11 & 39 & 1.429 & $0.000^{*}$ \\
\hline & Rural $n=50$ & 15 & 35 & & \\
\hline Thave stopped taking Oily foods & Urban $n=50$ & 27 & 23 & 5.911 & $0.015^{*}$ \\
\hline & Rural $\mathrm{n}=50$ & 23 & 27 & & \\
\hline I have stopped taking Diary food items & Urban $n=50$ & 20 & 30 & $0.36 /$ & $0.545^{3}$ \\
\hline & Rural $n=50$ & 26 & 24 & & \\
\hline I have stopped taking Sweet food & Urban $n=50$ & 34 & 16 & 2.667 & $0.102^{\mathrm{Nu}}$ \\
\hline & Rural $n=50$ & 36 & 14 & & \\
\hline I have stopped taking Caffeine & Urban $n=50$ & 21 & 29 & 9.180 & $0.002 *$ \\
\hline
\end{tabular}

\footnotetext{
* Significant, NS non significant
} 
Table 4: Comparison of Lifestyle Modification as a strategy adopted for weight control by nursing mothers residing in rural and urban areas $\mathrm{N}=100$

\begin{tabular}{|c|c|c|c|c|c|}
\hline Lifestyle Modifications as a Strategy & Area & Yes (f) & No (f) & Chi Test & 'p' Value \\
\hline \multirow{2}{*}{ I take dinner in early evening } & Rural $n=50$ & 18 & 32 & \multirow{2}{*}{1.714} & \multirow{2}{*}{$0.190^{\mathrm{NS}}$} \\
\hline & Urban $n=50$ & 12 & 38 & & \\
\hline \multirow{2}{*}{ I take medications for weight loss } & Rural $n=50$ & 20 & 30 & \multirow{2}{*}{4.762} & \multirow{2}{*}{$0.029 *$} \\
\hline & Urban $n=50$ & 10 & 40 & & \\
\hline \multirow{2}{*}{ I check my weight regularly } & Rural $n=50$ & 11 & 39 & \multirow{2}{*}{13.500} & \multirow{2}{*}{$0.000 *$} \\
\hline & Urban $n=50$ & 29 & 21 & & \\
\hline \multirow{2}{*}{ I am motivated to reduce weight } & Rural $n=50$ & 20 & 30 & \multirow{2}{*}{16.667} & \multirow{2}{*}{$0.000 *$} \\
\hline & Urban $\mathrm{n}=50$ & 40 & 10 & & \\
\hline \multirow{2}{*}{ I sleep for 06-08 hours straight regularly } & Rural $n=50$ & 30 & 20 & \multirow{2}{*}{0.694} & \multirow{2}{*}{$0.405^{\mathrm{NS}}$} \\
\hline & Urban $n=50$ & 34 & 16 & & \\
\hline \multirow{2}{*}{$\begin{array}{l}\text { I try to remain stress free by indulging in } \\
\text { leisure activity }\end{array}$} & Rural $n=50$ & 20 & 30 & \multirow{2}{*}{5.769} & \multirow{2}{*}{$0.016^{*}$} \\
\hline & Urban $\mathrm{n}=50$ & 32 & 18 & & \\
\hline
\end{tabular}

* Significant, NS non significant

\section{Discussion}

The investigator found that there was a nonsignificant relationship between the numbers of strategies adopted for weight with socio-demographic variables. Investigators also find that the nursing mothers residing in the urban area adopted more strategies for weight control as compare to nursing mother residing in the rural area. A study of 2,464 in the U.S. similarly found that the women who tried to lose or maintain their weight had adopted exercise more as a strategy than dietary changes. Women who were advised to maintain or gain weight were less as compared to women who were trying to lose weight. ${ }^{[18]}$

\section{Conclusion}

The finding shows that the number of strategies adopted for weight control by nursing mothers residing in the urban area was higher than mothers residing in the rural area. Controlled trials can be conducted to evaluate the effectiveness of specific strategies.

Acknowledgment: We would also like to thank Dr. Harmeet Kaur, Principal, Chitkara School of Health Sciences, Chitkara University, Punjab, India, for her unending guidance during the period of our study.

\section{Conflicts of Interest: None}

\section{Source of Funding: Self}

\section{References}

1. Dietary Guidelines - health.gov [Internet]. Health. gov. (2019) [cited 14 January 2019]. Available from: https:/health.gov/dietaryguidelines/2015/ guidelines/. Retrieved 20 January 2019.

2. Blackburn GL, Walker WA. Science-based solutions to obesity: what are the roles of academia, government, industry, and health care?-. The American journal of clinical nutrition. (2005) Jul 1;82(1):207S-10S.

3. ColdF, Health E, Disease H, Disease L, Management $\mathrm{P}$, Conditions $\mathrm{S}$ et al. The Mayo Clinic Diet Review [Internet]. WebMD. (2019) [cited 14 March 2019]. Available from: https:/www.webmd.com/diet/ features/the-mayo-clinic-diet»High-Protein Diet for Weight Loss». Retrieved 13 January 2019

4. FeingoldKR, Grunfeld C. The effect of inflammation and infection on lipids and lipoproteins. In Endotext [Internet] (2019) Jan 8. MD Text. com, Inc. Retrieved 21 January 2019.

5. Harmon K. Sleep might help dieters shed more fat. Scientific American. [Internet] (2010). Retrieved 20 January 2019.

6. Institute for Quality and Efficiency in Health Care. «Health benefits of losing weight». Fact sheet, Informed Health Online. (2017) Institute for Quality and Efficiency in Health Care. Retrieved 27 June 2018. 
7. Lau DC, Douketis JD, Morrison KM, Hramiak IM, Sharma AM, Ur E. (2006) Canadian clinical practice guidelines on the management and prevention of obesity in adults and children [summary]. Cmaj. 2007 Apr 10;176(8):S1-3.

8. LeBlanc, E; O'Connor, E; Whitlock, EP (2011). «Screening for and management of obesity and overweight in adults». Evidence Syntheses, No. 89. U.S. Agency for Healthcare Research and Quality (AHRQ). Retrieved 27 June 2018.

9. Nedeltcheva A, Kilkus J, Imperial J, Schoeller D, Penev P. Insufficient Sleep Undermines Dietary Efforts to Reduce Adiposity. Annals of Internal Medicine. (2010); 153(7):435.

10. Pathak K, Soares MJ, Calton EK, Zhao Y, Hallett J. Vitamin D supplementation and body weight status: a systematic review and meta-analysis of randomized controlled trials. Obesity reviews. (2014) Jun; 15(6):528-37.

11. Shick SM, Wing RR, Klem ML, McGUIRE MT, Hill JO, Seagle H. Persons successful at long-term weight loss and maintenance continue to consume a low-energy, low-fat diet. Journal of the American Dietetic Association. (1998) Apr 1;98(4):408-13.

12. Strychar I. Diet in the management of weight loss. Cmaj. (2006) Jan 3;174(1):56-63.

13. Sumithran P, Proietto J. The defence of body weight: a physiological basis for weight regain after weight loss. Clinical Science. (2013) Feb 1;124(4):231-41.

14. Tate DF, Jeffery RW, Sherwood NE, Wing RR. Long-term weight losses associated with prescription of higher physical activity goals. Are higher levels of physical activity protective against weight regain?. The American journal of clinical nutrition. (2007) Apr 1;85(4):954-9.

15. Thangaratinam S, Rogozińska E, Jolly K, Glinkowski S, Roseboom T, Tomlinson JW, Kunz R, Mol BW, Coomarasamy A, Khan KS. Effects of interventions in pregnancy on maternal weight and obstetric outcomes: meta-analysis of randomised evidence. Bmj. (2012) May 17;344:e2088.

16. Weight loss - Howling Pixel [Internet]. Howlingpixel.com. (2019) [cited 14 March 2019]. Available from: https://howlingpixel.com/i-en/ Weight_loss. Retrieved 13 January 2019.

17. Williams SG, Schmidt DK, Redd SC, Storms W. Key clinical activities for quality asthma care. Recommendations of the National Asthma Education and Prevention Program. MMWR Recommendations and Reports. (2003) Mar; 52 (RR-6):1-8.

18. Yeganeholadadam, N. Association between Weight Discrimination and Program Adherence in a Clinical Weight Management Program. (2016). 